\title{
Distribution of yellow-head virus in selected tissues and organs of penaeid shrimp Penaeus vannamei
}

\author{
Y. Lu$^{1}$, L. M. Tapay ${ }^{1}$, P. C. Loh ${ }^{1, *}$, J. A. Brock ${ }^{2}$, R. B. Gose ${ }^{2}$ \\ ${ }^{1}$ Department of Microbiology, University of Hawaii and ${ }^{2}$ Aquaculture Development Program, State of Hawaii, Honolulu, \\ Hawaii 96822 , USA
}

\begin{abstract}
The distribution of yellow-head virus (YHV) in 9 different tissues and organs including the branchial portion of the gill, nerve cord, lymphoid organ (Oka), heart, midgut, hepatopancreas, head soft tissues (HST), abdominal muscle, and eyestalk of experimentally infected moribund white shrimp Penaeus vannamei (Boone) was examined by bioassay using penaeid shrimp indicators and by quantal assay $\left(\mathrm{TCID}_{50}\right)$ in primary shrimp Oka organ cell cultures. Infectious YHV was demonstrated in all the tissues and organs tested; inoculation of each of the tissue and organ filtrates into experimental shrimp resulted in $100 \%$ mortality within 6 to $9 \mathrm{~d}$ postinfection. The TCID 50 assay in primary Oka organ cells revealed that Oka, gill and HST contained 10- to 800-fold higher titers of YHV than the other tissues and organs tested and suggested that they are apparently the primary target tissues and organs for YHV infection.
\end{abstract}

KEY WORDS: Yellow-head virus - Penaeid shrimp - TCID so assay

\section{INTRODUCTION}

Yellow-head virus (YHV) infections have been reported to cause massive losses of cultured penaeids Penaeus monodon in Southeast Asian countries such as Thailand (Boonyaratpalin et al. 1993). Early reports identified the YHV as a baculo-like virus (Boonyaratpalin et al. 1993. Chantanachookin et al. 1993). However, a recent report has indicated that the YHV is a RNA-containing virus probably belonging to either the Coronaviridae, Rhabdoviridae or Paramyxoviridae families (Wongteerasupaya et al. 1995).

In a previous paper, we reported the virulence of the YHV, then believed to be a baculo-like virus, for 2 main species of penaeid shrimp Penaeus stylirostris and $P$. vannamei cultured in Hawaii and the Western Hemisphere (Lu et al. 1994). Experimentally infected shrimp showed signs of disease as early as $2 \mathrm{~d}$ postinfection (p.i.) and in most cases, mortality reached $100 \%$ within 5 to $7 \mathrm{~d}$ p.i. Electron microscopy of thin sections of the gill and hepatopancreas from the in-

- Addressee for correspondence;

E-mail address: philip@hawaii.edu fected shrimp revealed enveloped, rod-shaped helical particles measuring 130 to $197 \times 45$ to $58 \mathrm{~nm}$ which were primarily localized within the cytoplasm of infected cells (Lu et al. 1994)

We recently reported the development of a $\mathrm{TCID}_{50}$ method to assay YHV using primary lymphoid organ cell cultures (Lu et al. 1995). Employment of this quantal assay method has enabled us to assess the distribution of infectious virus in the different tissues and organs of the experimentally infected animals, and to also determine the primary target organ(s) for YHV multiplication. This report describes our studies on the distribution of $\mathrm{YHV}$ in tissues and organs of experimentally infected Penaeus vannamei (Boone) using both bioassay and the $\mathrm{TCID}_{50}$ assay methods.

\section{MATERIALS AND METHODS}

YHV propagation. Twenty-four adult white shrimp Penaeus vannamei (approximately $20 \mathrm{~g}$ ) obtained from Mariculture Research and Training Center of Hawaii (MRTC) were placed into two 761 aquaria. For YHV propagation, each shrimp was inoculated intramuscu- 
larly (IM) with $0.15 \mathrm{ml}$ of a $15 \%$ suspension of cephalothorax tissue filtrate prepared from experimentally infected white shrimp. Moribund shrimp showing typical signs of yellow-head disease (YHD) were harvested from the tanks during the course of the infection ( 4 to $6 \mathrm{~d}$ ) and stored at $-70^{\circ} \mathrm{C}$. These shrimp were used later for the preparation of different tissue and organ suspensions. Ten uninfected shrimp were processed similarly to serve as controls.

Preparation of $10 \%$ tissue and organ suspensions. Frozen YHV-infected white shrimp were thawed and dissected. Nine different tissues and organs, including gill, hepatopancreas (HP), head soft tissue (HST), abdominal muscle (AM), eyestalk (ES), lymphoid organ (Oka), heart (HT), nerve cord (NC) and midgut (MG), were removed from the shrimp and similar tissues or organs were individually pooled. The pooled samples were homogenized by grinding with a mortar and pestle, and a $10 \%(\mathrm{w} / \mathrm{v})$ suspension was made with antibiotic incubation mixture $(10 \mathrm{ml}$ penicillin/streptomycin, $10000 \mathrm{IU} /$ $10000 \mu \mathrm{g} \mathrm{ml}^{-1}$; gentamicin, $0.5 \mathrm{ml}$ of $50 \mathrm{mg} \mathrm{ml}^{-1}$; amphotericin B, $1 \mathrm{ml}$ of $250 \mu \mathrm{g} \mathrm{ml}^{-1} ; 2 \mathrm{ml}$ salt solution; and $86.5 \mathrm{ml} 2 \times \mathrm{L} 15)$. Following centrifugation for $30 \mathrm{~min}$ at $3000 \times g$, the supernatant was further centrifuged for another $60 \mathrm{~min}$ at $12100 \times g$ at $4^{\circ} \mathrm{C}$. The recovered supernatant was then filtered through a $0.45 \mu \mathrm{m}$ porosity membrane and the filtrates aliquoted and stored at $-70^{\circ} \mathrm{C}$ for both YHV infection and titration.

Assaying YHV in shrimp indicators. Evaluation of the different tissues and organs of white shrimp for YHV infection was conducted by determining the mortality of shrimp indicators inoculated with the selected organ suspensions. Experimental white shrimp weighing 7 to $15 \mathrm{~g}$ were obtained from MRTC and maintained in $76 \mathrm{l}$ glass aquaria containing seawater (salinity 15 to $20 \mathrm{ppt}$. Bioassays were conducted at room temperature $\left(21\right.$ to $\left.25^{\circ} \mathrm{C}\right)$ and the experimental seawater was not changed during the experiments; the water was circulated through a filter as described previously (Lu \& Loh 1994).

For the infectivity experiments, each experimental glass aquarium contained equal numbers (12 to 18) of apparently healthy shrimp. The shrimp from each aquarium were then injected IM with one of the tissue and organ preparations, $0.10 \mathrm{ml}$ shrimp ${ }^{-1}$. Similarly, control shrimp were inoculated with corresponding tissue and organ filtrates prepared from uninfected white shrimp. The shrimp were observed daily; dead and moribund shrimp were removed and recorded daily for each of treatment groups during the course of the experiments. Cumulative mortalities were calculated and compared at the end of the test periods.

Titration of YHV in primary Oka cells. The titration of YHV in primary Oka cell cultures was conducted by the method described by Lu et al. (1995). Briefly, blue shrimp Penaeus stylirostris (20 to $30 \mathrm{~g}$ ) were purchased from Aquaculture Technology, Inc., a commercial shrimp farm in Hawail, for the preparation of primary Oka cell cultures. Oka were carefully removed from the shrimp and pooled. Following incubation for approximately $30 \mathrm{~min}$ in the antibiotic incubation mixture, the pooled Oka were minced into small fragments $\left(1 \mathrm{~mm}^{3}\right)$ and seeded into Primaria-grade 96 -well tissue culture plates. The explants were allowed to attach for $30 \mathrm{~min}$, and then shrimp cell culture medium (SCCM, consisting of double-strength L15, 20\% FBS, $4 \%$

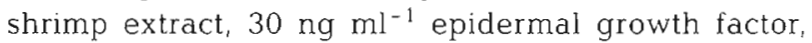
$100 \mu \mathrm{g} \mathrm{ml}^{-1}$ streptomycin, $100 \mathrm{IU} \mathrm{ml}^{-1}$ penicillin, $10 \mu \mathrm{g}$ $\mathrm{ml}^{-1}$ gentamicin, and $5 \mu \mathrm{g} \mathrm{ml}^{-1}$ amphotericin $\mathrm{B}$, osmolarity 730 to $\left.750 \mathrm{mOsm} \mathrm{kg} \mathrm{kg}^{-1}\right)$ was added $(0.2 \mathrm{ml}$ well ${ }^{-1}$ ). After 4 to $6 \mathrm{~d}$, Oka cell monolayers were formed and the titration of YHV was carried out by the method previously established in our laboratory (Lu et al. 1995). Primary Oka cell cultures inoculated with serum-deficient SCCM served as controls. All cultures were examined daily for cytopathogenic effect (CPE) and the $\mathrm{TCID}_{50}$ titer for each of the tissue and organ preparations was determined at $8 \mathrm{~d}$ p.i. using the method of Reed \& Muench (1938).

\section{RESULTS}

Several infectivity bioassays were conducted to evalwate the selected tissues and organs for infectious YHV. As summarized in Table 1, the results obtained from this experiment revealed the presence of infectious YHV in all the tissues and organs examined. Inoculation with the tissue and organ preparations resulted in typical YHD among all the experimentally infected shrimp and the cumulative mortality reached $100 \%$ in every infected group within 6 to $9 \mathrm{~d}$ p.i. Dead shrimp were observed as early as $2 \mathrm{~d}$ p.i. in groups inoculated with either gill or Oka preparations, and by Day 3 for the other groups. No survivors were observed in the shrimp injected with gill, Oka or HST samples after $6 \mathrm{~d}$ p.i., while in other groups cumulative mortalities ranged from 53 to $94 \%$. Cumulative mortality reached $100 \%$ at Day 7 for the group inoculated with MG sample, at Day 8 for HT-, AM- and NC-infected groups, and Day 9 for HP- and ES-treated groups. No mortalities were observed among the control shrimp

The results of the TCID 50 assay for YHV are summarized in Table 2. Primary cell cultures, when inoculated with tissue and organ filtrates from experimentally infected animals, all showed similar CPE. Visible CPE consisting of rounded and aggregated cells appeared as early as $3 \mathrm{~d}$ p.i. in the cultures inoculated with lower dilutions of the infected samples. As the infection progressed, the CPE became more extensive, and by 
Table 1. Penaeus vannamei. Mortality induced by inoculation of experimental shrimp ( 7 to $15 \mathrm{~g}$ ) with selected tissue and organ filtrates infected with yellow-head virus. HST head soft tissues; HT: heart; MG: midgut; HP: hepatopancreas; AM: abdominal muscle; ES: eyestalk; NC: nerve cord; G: branchial portion of the gills; Oka: lymphoid organ. No mortality was observed among the control shrimp inoculated with the corresponding tissue and organ filtrates processed from uninfected shrimp

\begin{tabular}{|c|c|c|c|c|c|c|c|c|c|}
\hline \multirow{2}{*}{$\begin{array}{l}\text { Day post- } \\
\text { infection }\end{array}$} & \multicolumn{9}{|c|}{ Cumulative mortajity $(\%)$} \\
\hline & $\mathrm{G}$ & Oka & HST & $\mathrm{MG}$ & $A M$ & NC & $\mathrm{HT}$ & $\mathrm{HP}$ & ES \\
\hline 1 & 0 & 0 & 0 & 0 & 0 & 0 & 0 & 0 & c \\
\hline 2 & 4 & 5 & 0 & 0 & 0 & 0 & 0 & 0 & $c$ \\
\hline 3 & 8 & 10 & 5 & 5 & 6 & 6 & 4 & 6 & 4 \\
\hline 4 & 48 & 38 & 36 & 23 & 25 & 19 & 22 & 17 & 17 \\
\hline 5 & 96 & 86 & 77 & 50 & 56 & 50 & 43 & 35 & 31 \\
\hline 6 & 100 & 100 & 100 & 77 & 75 & 75 & 70 & 53 & 56 \\
\hline 7 & & & & 100 & 94 & 94 & 91 & 71 & 87 \\
\hline 8 & & & & & 100 & 100 & 100 & 88 & 91 \\
\hline 9 & & & & & & & & 100 & 100 \\
\hline
\end{tabular}

Day 7 p.i, the affected cells detached from the surface of the container. The gill, Oka and HST suspensions yielded a YHV titer of 5 to $8 \times 10^{6}$ TCID $_{50}$ units $\mathrm{ml}^{-1}$ which was approximately 10 - to 800 -fold higher than the titers obtained with the other tissue and organ samples. The ES and HP contained the least amount of YHV in comparison to other tissues and organs. This test was repeated and similar results were obtained. No cytopathology was observed in primary Oka cell cultures inoculated with serum-deficient SCCM.

\section{DISCUSSION}

Determination of the distribution of the viral etiological agent in the tissues and organs of affected hosts is one of the important aspects for understanding viral disease. Furthermore, identification of the most susceptible target tissue(s) and organ(s) will greatly facilitate and enhance the recovery, isolation and detection

Table 2. Penaeus vannamei. Titers of yellow-head virus (YHV) determined in selected tissues and organs of white shrimp experimentally infected with YHV. TCID 50 assay was conducted at 21 to $25^{\circ} \mathrm{C}$ and titers were determined at $8 \mathrm{~d}$ postinfection. Uninfected primary Oka cell cultures did not show any cytopathology during the entire experimental period

\begin{tabular}{|lc|}
\hline Organ/tissue & TCID $_{50}$ titer $\left(\mathrm{ml}^{-1}\right)$ \\
\hline Branchial portion of the gill (G) & $8 \times 10^{6}$ \\
Lymphoid organ (Oka) & $8 \times 10^{6}$ \\
Head soft tissues (HST) & $5 \times 10^{6}$ \\
Midgut (MG) & $5.6 \times 10^{5}$ \\
Abdominal muscle (AM) & $3.1 \times 10^{5}$ \\
Heart (HT) & $1.5 \times 10^{5}$ \\
Nerve cord (NC) & $5.6 \times 10^{4}$ \\
Hepatopancreas (HP) & $1.1 \times 10^{4}$ \\
Eyestalk (ES) & $1.1 \times 10^{4}$ \\
\hline
\end{tabular}

of the viral agent. Except for rhabdovirus of penaeid shrimp whose multiplication was observed only in Oka of the infected shrimp (Nadala et al. 1992), there is little information available concerning the exact distribution of other infectious shrimp viruses in their respective hosts. This is due to the lack of relatively simple technologies, such as shrimp cell culture, to carry out such a study.

In our current study, the distribution of YHV in various tissues and organs of white shrimp Penaeus vannamei was analyzed by both bioassay and cell culture methods. The results from the bioassay denoted that inoculation of the different sample preparations resulted in death of all the experimental shrimp within 6 to $9 \mathrm{~d}$ p.i. and strongly implied the presence of infectious virus in all these tissues and organs. Filtrates of Oka, gill and HST samples caused $100 \%$ mortality earlier (within $6 \mathrm{~d}$ p.i.), in comparison to 8 to $9 \mathrm{~d}$ for the other tissues and organs. This suggests that Oka, gill and head muscle may contain more infectious virus than other tissues and organs and implies that they may be more predisposed to infection with YHV.

The development of the TCID $_{50}$ assay using primary Oka cell cultures allowed for the quantitative assay of the different tissues and organs of penaeid hosts for YHV. The data obtained from this cell culture assay is consistent with the findings in bioassays and confirmed the wide distribution of YHV in shrimp tissues and organs. Comparison of infectious YHV titers in these selected tissues and organs revealed that Oka, gill and HST are among the highest, strongly indicating that these tissues and organs best supported multiplication of YHV. These results also suggest that Oka, gill and HST are the most susceptible targets and they should be the primary tissues used for YHV isolation and for YHD diagnosis.

Our previous study demonstrated that rod-shaped YHV particles were concentrated largely within the 
cytoplasm of the infected gill cells of infected shrimp within a short period of time ( $4 \mathrm{~d}$ p.i.). Histopathological examinations showed different degrees of cellular necrosis in many organs including body, gill, fore- and hindgut, connective tissues, hemocytes, hematopoietic organs, heart, hepatopancreas and lymphoid organ (Lu et al. 1995). This study revealed the presence of infectious YHV in a wide variety of tissues and organs examined. Previous data together with these results indicate the wide distribution and rapid multiplication of YHV in the host shrimp and clearly explain why the virus is one of the most virulent viruses identified so far in cultured penaeid shrimp. The infection results in massive mortalities of affected shrimp within a very short incubation time. A more comprehensive examination of the distribution of YHV in other tissues and organs, such as hematopoietic tissue, Y organ, stomach, antennal gland, periopods and pleopods should be conducted to determine further the pathogenesis of YHV infection.

Acknowledgements. This research was supported by grants from the University of Hawaii Sea Grant and College Program, Institutional Grant No. NA36RG0507, UNIHI-SEAGRANT-JC-94-44, and the Aquaculture Development Program, Department of Land and Natural Resources, State of Hawaii Contract No. 35963

Responsible Subject Editor: J. E. Stewart, Dartmouth, Nova Scotia, Canada

\section{LITERATURE CITED}

Boonyaratpalin S, Supamattaya K, Kasornchandra J, Direkbusaracom $S$, Aekpanithanpong $U$, Chantanachooklin C (1993) Non-occluded baculo-like virus, the causative agent of yellow head disease in the black tiger shrimp (Penaeus monodon). Gyobyo Kenkyu 28(3):103-109

Chantanachookin C, Boonyaratpalin S, Kasornchandra J, Direkbusarakom S, Ekpanithanpong U, Supamataya $\mathrm{K}$ Sriurairatana S, Flegel TW (1993) Histology and ultrastructure reveal a new granulosis-like virus in Penaeus monodon affected by yellow-head virus. Dis aquat Org 17 $145-157$

Lu Y, Loh PC (1994) Infectivity studies of rhabdovirus in penaeid blue shrimp. Aquacult Int 2:123-127

Lu Y, Tapay LM, Loh PC, Brock JA (1994) Infection of the yellow head baculo-like virus in two species of penaeid shrimp, $P$ stylirostris and $P$ vannamei. J Fish Dis 17 649-656

Lu Y, Tapay LM, Loh PC, Brock JA, Gose R (1995) Development of a quantal assay in primary shrimp cell culture for yellow head baculovirus (YBV) of penaeid shrimp. $J$ virol Meth (in press)

Nadala ECB Jr, Lu Y, Loh PC (1992) Infection of Penaeus stylirostris (Boone) with a rhabdovirus isolated from Penaeus spp. Gyobyo Kenkyu 27(3):143-147

Reed LJ, Muench $H$ (1938) A simple method of estimating fifty percent end-points. Am J Hygiene 27:493-497

Wongteerasupaya C, Sriurairatana S, Vickers JE, Akrajamorn A, Boonsaeng V, Panyim S, Tassanakajon A, Withyachumnarnkul B, Flegel TW (1995) Yellow-head virus of Penaeus monodon is an RNA virus. Dis aquat Org 22:45-50

Manuscript first received: November 30, 1994

Revised version accepted: May 29, 1995 